\title{
Does the methacholine test reproduce symptoms?
}

\author{
Marianne Lévesque MD, Heberto Ghezzo PhD, Jocelyne L'Archevêque RT, Jean-Luc Malo MD
}

M Lévesque, H Ghezzo, J L'Archevêque, J-L Malo. Does the methacholine test reproduce symptoms? Can Respir J 2010;17(5): 224-228.

BACKGROUND: The interpretation of methacholine test results do not usually consider the symptoms for which the subject was referred and those that occur during the test.

OBJECTIVE: To assess the association between methacholine test results and symptoms, and to examine variables that may affect this association. METHODS: A total of 400 prospectively chosen subjects who underwent methacholine testing for possible asthma were investigated. The subjects answered a short questionnaire regarding the symptoms for which they had been referred and those that were encountered during the methacholine test.

RESULTS: The positive predictive value for the reproduction of symptoms during the test compared with symptoms for which subjects had been referred were $84 \%$ for dyspnea, $87 \%$ for cough, $81 \%$ for wheezing and $72 \%$ for chest tightness. The positive predictive value among the values obtained by measuring the provocative concentration of methacholine causing a $20 \%$ fall $\left(\mathrm{PC}_{20}\right)$ in forced expiratory volume in $1 \mathrm{~s}$ on the one hand, and specific symptoms on the other, varied by up to approximately $50 \%$; negative predictive values were higher. Forty-eight per cent of subjects with a $\mathrm{PC}_{20}$ of $16 \mathrm{mg} / \mathrm{mL}$ or lower reported that the test had globally reproduced their symptoms. This association was significantly stronger in women, young subjects and those taking inhaled steroids.

CONCLUSIONS: The methacholine test generally reproduced the symptoms for which the subjects were referred. The absence of a specific symptom (eg, dyspnea, cough, wheezing or chest tightness), either in daily life or at the time of methacholine testing, was more generally associated with a negative test than the reverse. The global impression that the test had reproduced what the patient had experienced in daily life was significantly associated with a positive test (ie, a $\mathrm{PC}_{20}$ of $16 \mathrm{mg} / \mathrm{mL}$ or lower), with the association being stronger in young subjects and women.

Key Words: Asthma; Methacholine testing; Nonspecific bronchial responsiveness

$\mathrm{A}$ sthma is characterized by the presence of respiratory symptoms, of which wheezing is the most specific. However, these symptoms can also be present in other upper and lower respiratory diseases. Therefore, it is recommended that the diagnosis of asthma be supported by objective functional or inflammatory evidence (1). The optimal epidemiological definition of asthma is a combination of respiratory symptoms and documented bronchial hyper-responsiveness (2). If the airway calibre is normal, it generally precludes the documentation of significant improvement after administering an inhaled bronchodilator, which justifies testing for nonspecific bronchial responsiveness. Methacholine testing is currently widely used in this regard because it is highly standardized $(3,4)$ and safe $(5)$. There are discrepancies between the clinical impression that a patient may suffer from asthma and the results of methacholine testing (6). Generally, results of methacholine testing are interpreted without information

\section{Le test à la méthacholine reproduit-il les symptômes?}

HISTORIQUE : En général, l'interprétation des résultats du test à la méthacholine ne tient pas compte des symptômes pour lesquels le sujet a été aiguillé et ceux qui se produisent pendant le test.

OBJECTIF : Évaluer l'association entre les résultats du test à la méthacholine et les symptômes et examiner les variables susceptibles d'influer sur cette association.

MÉTHODOLOGIE : Au total, 400 sujets sélectionnés de manière prospective qui ont subi un test à la méthacholine en raison d'un asthme possible ont fait l'objet d'une évaluation. Les sujets ont répondu à un court questionnaire au sujet des symptômes pour lesquels ils ont été aiguillés et de ceux qui ont été observés pendant le test à la méthacholine.

RÉSULTATS : La valeur prédictive positive de la reproduction des symptômes pendant le test par rapport aux symptômes pour lesquels les sujets avaient été aiguillés était la dyspnée dans 84 \% des cas, la toux dans $87 \%$ des cas, la respiration sifflante dans $81 \%$ des cas et l'oppression dans $72 \%$ des cas. La valeur prédictive positive parmi les valeurs obtenues en mesurant la concentration provocatrice de méthacholine entraînant une chute de $20 \%\left(\mathrm{CP}_{20}\right)$ du volume expiratoire maximal par seconde d'une part, et des symptômes spécifiques d'autre part, variait jusqu'à environ 50 \%. Les valeurs prédictives négatives étaient plus élevées. Quarante-huit pour cent des sujets ayant une $\mathrm{CP}_{20}$ de $16 \mathrm{mg} / \mathrm{mL}$ ou moins déclaraient que le test reproduisait globalement leurs symptômes. Cette association était considérablement plus solide chez les femmes, les jeunes sujets et les personnes qui prenaient des stéroïdes en aérosol.

CONCLUSIONS : En général, le test à la méthacholine reproduisait les symptômes pour lesquels le sujet était aiguillé. L'absence de symptômes spécifique (p. ex., dyspnée, toux, respiration sifflante ou oppression), dans la vie quotidienne ou au moment du test à la méthacholine, s'associait plus généralement à un test négatif que l'inverse. L'impression globale selon laquelle le test reproduisait ce que le patient expérimentait dans sa vie quotidienne s'associait de manière significative à un test positif (c'est-àdire une $\mathrm{CP}_{20}$ de $16 \mathrm{mg} / \mathrm{mL}$ ou moins), l'association étant plus marquée chez les jeunes sujets et chez les femmes.

specific to the precise symptomatology that the patient is referred for, or information regarding symptoms at the time of testing. Some (7) have suggested that the inclusion of this information may be valuable in interpreting methacholine test results.

We prospectively assessed 400 subjects who had been referred to a lung function laboratory at a tertiary care hospital to assess the following: the correspondence between symptoms that subjects were referred for and those encountered at the time of testing; correspondence between symptoms and results of the methacholine test; and anthropometric, clinical and functional factors that may affect the correspondence of symptoms and methacholine results. We hypothesized that asthma symptoms were more likely to be reproduced in subjects with a positive methacholine test, and that taking antiasthmatic medication at the time of testing was significantly associated with a positive methacholine test.

Department of Chest Medicine, Sacré-Coeur Hospital, Université de Montréal, Montréal, Québec

Correspondence: Dr Jean-Luc Malo, Department of Chest Medicine, Sacré-Coeur Hospital, 5400 Gouin Boulevard West, Montréal,

Québec H4J 1C5. Telephone 514-338-2796, fax 514-338-3123, e-mail maloj@meddir.umontreal.ca 


\section{METHODS}

Subjects

Between June 2008 and February 2009, all adult subjects who were referred to the Department of Chest Medicine, Sacré-Coeur Hospital (Montreal, Quebec) for methacholine testing were asked to complete a questionnaire regarding respiratory symptoms for which they had been referred for testing and the symptoms they encountered during the test. In addition, information regarding whether symptoms had occurred in the two weeks preceding testing was obtained. Finally, subjects were asked to answer the following question: 'Do you think that the symptoms you experienced during the test are similar to those for which you saw a doctor and the test was performed?' Possible answers were the following: 'exactly the same', 'very similar', 'similar', 'not very similar' and 'not similar'. The present investigation followed the example of a study by Stenton et al (7), who asked about the reproducibility of symptoms occurring during the methacholine test compared with those experienced during testing by asking the following simple question: 'Have you ever felt like this before?' The protocol was accepted by the Ethics Review Board of Sacré-Coeur Hospital. A consent form was not required from the participants because the symptom questionnaire was already included in the clinical protocol of the methacholine test. The analysis was, therefore, retrospective, although subjects were included prospectively.

Spirometry was assessed according to practice standards (8). Patients taking a short-acting inhaled bronchodilator had their medication stopped $12 \mathrm{~h}$ before testing, while patients who were taking long-acting inhaled bronchodilators had their medication stopped $36 \mathrm{~h}$ before testing, according to recommendations (4). Methacholine testing was performed using a Wright's nebulizer (output $0.14 \mathrm{~mL} / \mathrm{min}$ ) according to a standardized procedure (9), using concentrations of up to $32 \mathrm{mg} / \mathrm{mL}$ depending on the response. The provocative concentration of methacholine causing a $20 \%$ fall $\left(\mathrm{PC}_{20}\right)$ in forced expiratory volume in $1 \mathrm{~s}\left(\mathrm{FEV}_{1}\right)$ was intrapolated from dose-response curves drawn on a semilogarithmic scale and, in the case of a $\mathrm{PC}_{20}$ of $32 \mathrm{mg} / \mathrm{mL}$ or higher, the maximum fall in $\mathrm{FEV}_{1}$ was recorded. A positive methacholine test was defined as a $\mathrm{PC}_{20}$ of $16 \mathrm{mg} / \mathrm{mL}$ or lower (10). Reference values for spirometry were adapted from those of Knudson et al (11).

The following patient information was available: anthropometric data regarding age, height and weight; functional data regarding $\mathrm{FEV}_{1}, \mathrm{FEV}_{1} /$ forced vital capacity (FVC) in per cent predicted; and $\mathrm{PC}_{20}$ in $\mathrm{mg} / \mathrm{mL}$. Logarithmic transformation of $\mathrm{PC}_{20}$ was used in the analysis.

\section{Statistical analysis}

The correspondence between symptoms for which subjects had been referred and those that were experienced during testing, and symptoms and results of the $\mathrm{PC}_{20}$ test were examined using $2 \times 2$ tables, positive and negative predictive values and the $\chi^{2}$ test. Subjects were categorized as those in whom the test had globally reproduced their symptoms (answering 'the same,' 'very similar' and 'similar' to a general question [see above]) and others. The anthropometric, clinical and functional variables were compared in the two groups using the $\chi^{2}$ test or the Student's unpaired $t$ test. The generalized linear model analysis was applied to the multivariate analysis using variables that were significant at $\mathrm{P}<0.1$ in the univariate analysis. SPSS version 16 (SPSS Inc, USA) was used for statistical testing.

\section{TABLE 1}

\section{Subject characteristics $(n=400)$}

\begin{tabular}{lc}
\hline Age, years (mean $\pm \mathrm{SD}$ ) & $50.4 \pm 15.1$ \\
Sex, male/female, $\mathrm{n}(\%)$ & $168(42) / 232(58)$ \\
Medication & \\
None & $188(47.0)$ \\
Short-acting bronchodilator on demand only & $65(16.2)$ \\
Inhaled corticosteroids regularly & $151(37.8)$ \\
Baseline $\mathrm{FEV}_{1}, \%$ predicted (mean $\pm \mathrm{SD}$ ) & $97.2 \pm 15.8$ \\
Subjects with values $<80 \%$ of predicted & $53(13.2)$ \\
Baseline $\mathrm{FEV}_{1} / \mathrm{FVC}, \%$ (mean $\left.\pm \mathrm{SD}\right)$ & $79.0 \pm 7.7$ \\
Subjects with values $<70 \%$ & $49(12.3)$ \\
Symptoms present in the previous two weeks & $261(65.2)$ \\
$\mathrm{PC}_{20}, \mathrm{mg} / \mathrm{mL}$ & \\
$<0.25$ & $5(1.2)$ \\
0.25 to $<2$ & $42(10.5)$ \\
2 to $<8$ & $64(16.0)$ \\
8 to 16 & $64(16.0)$ \\
$>16$ & $225(56.2)$ \\
\hline
\end{tabular}

Data presented as $n$ (\%) unless indicated otherwise. FEV ${ }_{1}$ Forced expiratory volume in $1 \mathrm{~s}$; FVC Forced vital capacity; $P C_{20}$ Provocative concentration of methacholine causing a 20\% fall in FEV 1

\section{RESULTS}

A total of 400 subjects underwent methacholine testing during the study period and all completed the questionnaire. Their characteristics are presented in Table 1. There were more women, approximately one-half of whom were not taking any respiratory medication at the time of testing, with approximately one-third being on inhaled steroids. The majority of subjects had experienced symptoms in the two weeks preceding testing. $\mathrm{PC}_{20}$ values of $16 \mathrm{mg} / \mathrm{mL}$ or lower were obtained in $44 \%$ of the subjects.

Not shown in Table 1, taking inhaled steroids was associated with a positive methacholine test, with 82 of 151 subjects $(54 \%)$ on inhaled steroids recording a $\mathrm{PC}_{20}$ of $16 \mathrm{mg} / \mathrm{mL}$ or lower $(\mathrm{P}=0.001)$. Table 2 shows the percentage of subjects who demonstrated significant hyper-responsiveness according to the presenting symptoms and symptoms at the time of testing. These percentages neared $50 \%$ and rose as a function of the number of symptoms.

The associations between symptoms for which subjects were referred and those that occurred during the tests are presented in Table 3. Dyspnea and coughing were the most common symptoms and are those for which the positive predictive values (PPVs) were the highest. Testing was more likely to reproduce symptoms of daily life (higher PPV and lower negative predictive value [NPV]) than the reverse.

The associations between symptoms for which the subject had been referred and the results of the methacholine test are shown in Table 4. The PPV for which symptoms of dyspnea and wheezing would be associated with a positive $\mathrm{PC}_{20}$ (ie, $16 \mathrm{mg} / \mathrm{mL}$ or lower) was approximately $50 \%$, but the NPV - that is, the likelihood that the same symptoms would not be reproduced in the presence of a $\mathrm{PC}_{20}$ test result of greater than $16 \mathrm{mg} / \mathrm{mL}$ - was higher. The same conclusions can be reached by examining Table 5, which includes symptoms encountered during the test. The PPV of having a $\mathrm{PC}_{20}$ of $16 \mathrm{mg} / \mathrm{mL}$ in the presence of four respiratory symptoms justifying referral was $60.8 \%$, 
TABLE 2

Symptoms and results of methacholine testing

\begin{tabular}{lr}
\hline Symptoms for which subjects were referred $\left(\mathrm{PC}_{\mathbf{2 0}} \leq 16 \mathbf{~ m g} / \mathbf{m L}\right)$ \\
\hline Dyspnea $(\mathrm{n}=267)$ & $125(46.8)$ \\
Cough $(\mathrm{n}=307)$ & $128(41.7)$ \\
Wheezing $(\mathrm{n}=199)$ & $99(49.7)$ \\
Tightness in the chest $(\mathrm{n}=185)$ & $90(48.6)$ \\
One symptom ( $\mathrm{n}=79)$ & $25(31.6)$ \\
Two symptoms ( $\mathrm{n}=105)$ & $37(35.2)$ \\
Three symptoms ( $\mathrm{n}=132)$ & $58(43.9)$ \\
Four symptoms ( $\mathrm{n}=68)$ & $42(61.8)$ \\
Symptoms experienced during methacholine testing & \\
\hline Dyspnea $(\mathrm{n}=227)$ & $111(48.9)$ \\
Cough $(\mathrm{n}=232)$ & $107(46.1)$ \\
Wheezing $(\mathrm{n}=121)$ & $61(50.4)$ \\
Tightness in the chest $(\mathrm{n}=185)$ & $90(48.9)$ \\
One symptom $(\mathrm{n}=94)$ & $34(36.1)$ \\
Two symptoms $(\mathrm{n}=113)$ & $51(45.1)$ \\
Three symptoms ( $\mathrm{n}=96)$ & $51(53.1)$ \\
Four symptoms $(\mathrm{n}=39)$ & $20(51.3)$ \\
\hline
\end{tabular}

Data presented as $n$ (\%). $P C_{20}$ Provocative concentration of methacholine causing a $20 \%$ fall in forced expiratory volume in $1 \mathrm{~s}$

TABLE 3

Association between symptoms for which subjects were referred and those that were experienced during methacholine testing

\begin{tabular}{lccc}
\hline & \multicolumn{2}{c}{ Predictive value, \% (95\% Cl) } & \\
\cline { 2 - 3 } Symptom & Positive & Negative & P \\
\hline Dyspnea $(\mathrm{n}=191)$ & 84.1 & 56.1 & $<0.001$ \\
& $(78.8-88.3)$ & $(48.6-63.3)$ & \\
Cough $(\mathrm{n}=201)$ & 86.6 & 36.9 & $<0.001$ \\
& $(81.7-90.4)$ & $(30.3-44.4)$ & \\
Wheezing $(\mathrm{n}=98)$ & 81.0 & 63.8 & $<0.001$ \\
& $(73.1-87.0)$ & $(58.0-69.2)$ & \\
Chest tightness $(\mathrm{n}=133)$ & 71.9 & 75.8 & $<0.001$ \\
& $(65.0-77.9)$ & $(69.7-81.1)$ & \\
\hline
\end{tabular}

The number of subjects for each symptom represents those subjects who reported the specific symptom both before being referred and at the time of methacholine testing

while the NPV was $62.1 \%$. In the case of the presence of three symptoms, the PPV was $54.8 \%$ and the NPV $61.9 \%$. Limiting the analysis to the group of subjects who had experienced symptoms during the two weeks that preceded testing did not change the overall pattern of results.

Table 6 shows some characteristics of subjects who reported that the test had reproduced their symptoms $(\mathrm{n}=240) \mathrm{com}$ pared with those for whom this was not the case $(n=160)$. There were marginally more women and younger subjects in those with positive correspondence and significantly more subjects taking inhaled steroids. Also, baseline spirometry tended to be lower whereas the association level of $\mathrm{PC}_{20}$ was equivalent. In the multivariate analysis, sex (women greater than men, OR 149; 95\% CI 0.98 to 2.25; $\mathrm{P}=0.06$ ) and age (OR 0.99; $95 \% \mathrm{CI} 0.97$ to $1.0 ; \mathrm{P}=0.06$ ) remained marginally significant.
TABLE 4

Association between symptoms for which subjects were referred and the result of methacholine testing

\begin{tabular}{|c|c|c|c|}
\hline \multirow[b]{2}{*}{ Symptom } & \multicolumn{2}{|c|}{ Predictive value, $\%$} & \multirow[b]{2}{*}{$\mathbf{P}$} \\
\hline & Positive & Negative & \\
\hline \multicolumn{4}{|l|}{ Dyspnea (n=267) } \\
\hline $\mathrm{PC}_{20}<2 \mathrm{mg} / \mathrm{mL}$ & 14.6 & 94.0 & 0.01 \\
\hline $\mathrm{PC}_{20}<8 \mathrm{mg} / \mathrm{mL}$ & 33.0 & 82.7 & 0.001 \\
\hline $\mathrm{PC}_{20} \leq 16 \mathrm{mg} / \mathrm{mL}$ & 49.4 & 67.7 & 0.001 \\
\hline \multicolumn{4}{|l|}{ Cough $(n=307)$} \\
\hline $\mathrm{PC}_{20}<2 \mathrm{mg} / \mathrm{mL}$ & 12.4 & 90.3 & 0.48 \\
\hline $\mathrm{PC}_{20}<8 \mathrm{mg} / \mathrm{mL}$ & 28.3 & 74.2 & 0.63 \\
\hline $\mathrm{PC}_{20} \leq 16 \mathrm{mg} / \mathrm{mL}$ & 43.3 & 54.8 & 0.75 \\
\hline \multicolumn{4}{|l|}{ Wheezing (n=199) } \\
\hline $\mathrm{PC}_{20}<2 \mathrm{mg} / \mathrm{mL}$ & 18.1 & 94.5 & $<0.001$ \\
\hline $\mathrm{PC}_{20}<8 \mathrm{mg} / \mathrm{mL}$ & 35.7 & 80.1 & $<0.001$ \\
\hline $\mathrm{PC}_{20} \leq 16 \mathrm{mg} / \mathrm{mL}$ & 52.3 & 64.7 & 0.001 \\
\hline \multicolumn{4}{|c|}{ Chest tightness $(n=185)$} \\
\hline $\mathrm{PC}_{20}<2 \mathrm{mg} / \mathrm{mL}$ & 15.7 & 91.6 & 0.02 \\
\hline $\mathrm{PC}_{20}<8 \mathrm{mg} / \mathrm{mL}$ & 34.6 & 78.1 & 0.005 \\
\hline $\mathrm{PC}_{20} \leq 16 \mathrm{mg} / \mathrm{mL}$ & 50.3 & 61.9 & 0.02 \\
\hline
\end{tabular}

$P C_{20}$ Provocative concentration of methacholine causing a $20 \%$ fall in forced expiratory volume in $1 \mathrm{~s}$

TABLE 5

Association between symptoms experienced during methacholine testing and the result of methacholine testing

\begin{tabular}{|c|c|c|c|}
\hline \multirow[b]{2}{*}{ Symptom } & \multicolumn{2}{|c|}{ Predictive value, \% } & \multirow[b]{2}{*}{$\mathbf{P}$} \\
\hline & Positive & Negative & \\
\hline \multicolumn{4}{|l|}{ Dyspnea (n=227) } \\
\hline $\mathrm{PC}_{20}<2 \mathrm{mg} / \mathrm{mL}$ & 13.2 & 90.2 & 0.30 \\
\hline $\mathrm{PC}_{20}<8 \mathrm{mg} / \mathrm{mL}$ & 32.2 & 78.0 & 0.02 \\
\hline $\mathrm{PC}_{20} \leq 16 \mathrm{mg} / \mathrm{mL}$ & 50.7 & 65.3 & 0.001 \\
\hline \multicolumn{4}{|l|}{ Cough $(n=232)$} \\
\hline $\mathrm{PC}_{20}<2 \mathrm{mg} / \mathrm{mL}$ & 11.2 & 87.5 & 0.69 \\
\hline $\mathrm{PC}_{20}<8 \mathrm{mg} / \mathrm{mL}$ & 27.6 & 72.0 & 0.93 \\
\hline $\mathrm{PC}_{20} \leq 16 \mathrm{mg} / \mathrm{mL}$ & 47.4 & 61.3 & 0.08 \\
\hline \multicolumn{4}{|l|}{ Wheezing (n=121) } \\
\hline $\mathrm{PC}_{20}<2 \mathrm{mg} / \mathrm{mL}$ & 14.9 & 89.6 & 0.20 \\
\hline $\mathrm{PC}_{20}<8 \mathrm{mg} / \mathrm{mL}$ & 32.2 & 74.2 & 0.19 \\
\hline $\mathrm{PC}_{20} \leq 16 \mathrm{mg} / \mathrm{mL}$ & 52.9 & 60.2 & 0.02 \\
\hline \multicolumn{4}{|c|}{ Chest tightness $(n=185)$} \\
\hline $\mathrm{PC}_{20}<2 \mathrm{mg} / \mathrm{mL}$ & 15.1 & 91.2 & 0.05 \\
\hline $\mathrm{PC}_{20}<8 \mathrm{mg} / \mathrm{mL}$ & 31.4 & 75.3 & 0.14 \\
\hline $\mathrm{PC}_{20} \leq 16 \mathrm{mg} / \mathrm{mL}$ & 51.4 & 62.8 & 0.004 \\
\hline
\end{tabular}

$P C_{20}$ Provocative concentration of methacholine causing a $20 \%$ fall in forced expiratory volume in $1 \mathrm{~s}$

\section{DISCUSSION}

In subjects referred for methacholine testing, our study demonstrated the following: there was a good correspondence between symptoms justifying referral and those experienced during the test, with high PPVs (more than 80\% for dyspnea, cough and wheezing) regardless of the result of methacholine testing (Table 3); the absence of a specific symptom (eg, dyspnea, cough, wheezing or chest tightness) either in daily life or at the time of methacholine testing was more generally associated with a negative metacholine test than the reverse (higher NPVs shown in Tables 4 and 5); the correspondence with the global impression expressed by subjects that the test had 
reproduced or had not reproduced daily life symptoms was significantly associated with the $\mathrm{PC}_{20}$ test result, the correspondence being slightly higher ( $47.9 \%$ versus $37.5 \%)$ in subjects with a $\mathrm{PC}_{20}$ value of $16 \mathrm{mg} / \mathrm{mL}$ or lower (Table 6).

The PPV of a $\mathrm{PC}_{20}$ of $16 \mathrm{mg} / \mathrm{mL}$ or lower to be associated with a specific respiratory symptom, either in daily life or at the time of testing, was close to $50 \%$. In other studies, significant positive associations have previously been shown, but these were generally relatively modest, varying from $35 \%$ in the study by Pratter et al (12), to $28 \%$ to $67 \%$ in the study by Dales et al (13), and were dependent on the threshold of responsiveness that was selected. In a recent study by Yurdakul et al (14), the PPV was $70 \%$ for wheezing and $67 \%$ for coughing. However, that study included frank asthmatic subjects (which was not the case in our study because subjects were referred for confirmation) and who the authors referred to as 'pseudoasthmatic' subjects. The PPV was higher if the threshold of responsiveness was higher - from $2 \mathrm{mg} / \mathrm{mL}$ to $16 \mathrm{mg} / \mathrm{mL}$, as assessed in our study. The NPVs were higher in our study, which suggests that the absence of specific symptoms was more generally associated with negative methacholine test results than the reverse. The incapacity of methacholine testing to reproduce symptoms of daily life may be linked to different factors. The perception of breathlessness seems to be lower in subjects without airway obstruction (which was the case in the majority of our subjects) and does not seem to be related to bronchial hyper-responsiveness (15). It may also be linked to the indirect nature of this particular pharmacological stimulus. It is known that histamine induces more coughing than methacholine. Using exercise as a stimulus may be a better reflection of dyspnea, while inhaling cold air would cause more coughing. Therefore, the nature of the stimulus is also a significant factor that should be considered when interpreting the correspondence between symptoms and the results of nonspecific bronchial responsiveness testing.

We included a general question on the subject's general perception of symptoms experienced during the methacholine test. For this, we followed the example of the study by Stenton et al (7), who showed that a positive answer to such a global question was significantly associated with the result of methacholine testing, whereas answers to detailed questions (wheezing, chest tightness, coughing and breathlessness) did not justify this approach. Our results confirm these findings. As mentioned above, a positive answer to this global question on the reproducibility of symptoms was slightly more often found in subjects with a $\mathrm{PC}_{20}$ of $16 \mathrm{mg} / \mathrm{mL}$ or lower $(47.9 \%)$, while those with a negative answer had a $\mathrm{PC}_{20}$ of $16 \mathrm{mg} / \mathrm{mL}$ or lower slightly but significantly less often $(37.5 \%)$. We examined factors that were associated with a correspondence between the perception of symptoms and a positive methacholine test. In the univariate analysis, several factors were identified - a positive correspondence was more likely to occur in women, in younger subjects and in subjects taking inhaled steroids. Devereux et al (16) showed that the perception of bronchoconstriction is better in young subjects and in women, as well as in subjects who report more than one respiratory symptom. Taking inhaled steroids may have had conflicting effects. On the one hand, physicians who referred patients for testing may have considered subjects who were prescribed inhaled steroids as probably experiencing more intractable typical symptoms of asthma
TABLE 6

Comparison of characteristics between groups with and without clinical and functional correspondence

\begin{tabular}{|c|c|c|c|}
\hline \multirow[b]{2}{*}{ Characteristic } & \multicolumn{2}{|c|}{ Correspondence } & \multirow[b]{2}{*}{$\mathbf{P}$} \\
\hline & $\begin{array}{l}\text { Positive } \\
(n=240)\end{array}$ & $\begin{array}{l}\text { Negative } \\
(n=160)\end{array}$ & \\
\hline Sex, male/female (\%) & $38 / 62$ & $47.5 / 52.5$ & 0.07 \\
\hline Age, years & $49.3 \pm 14.7$ & $52.0 \pm 15.5$ & 0.07 \\
\hline $\begin{array}{l}\text { Taking short-acting } \\
\text { bronchodilator on demand only, \% }\end{array}$ & 42.5 & 55.0 & 0.01 \\
\hline Taking inhaled corticosteroids, \% & 43.3 & 29.4 & 0.005 \\
\hline Baseline $\mathrm{FEV}_{1}, \%$ predicted & $96.2 \pm 15.4$ & $98.7 \pm 16.3$ & 0.12 \\
\hline \multicolumn{4}{|l|}{ Level of $\mathrm{PC}_{20}, \mathrm{mg} / \mathrm{mL}(\%)$} \\
\hline$<2$ & 14.2 & 8.1 & 0.07 \\
\hline$<8$ & 30.8 & 23.1 & 0.09 \\
\hline$\leq 16$ & 47.9 & 37.5 & 0.04 \\
\hline
\end{tabular}

Data presented as mean \pm SD unless otherwise indicated. A positive correspondence is defined by answering 'exactly the same', 'very similar' or 'similar' to the question, 'Do you think that the symptoms that you experienced during the test are similar to those for which you saw a doctor and the test was performed?' A negative correspondence is defined by answering 'not very similar' or 'not similar' to the same question. FEV $V_{1}$ Forced expiratory volume in $1 \mathrm{~s}$; $P C_{20}$ Provocative concentration of methacholine causing a $20 \%$ fall in FEV ${ }_{1}$

(eg, predominant wheezing). On the other hand, inhaled steroids may have 'blunted' bronchial responsiveness by attenuating airway inflammation, which may have led to a diminished perception of symptoms.

The results of our study have clinical and therapeutic implications. First, the interpretation of the methacholine test should include information on the symptoms encountered during testing. In this regard, a methacholine test is more likely to be negative if the $\mathrm{PC}_{20}$ is $16 \mathrm{mg} / \mathrm{mL}$ or higher, and no specific symptom was reproduced during the test. Similarly, our finding that the global impression expressed by the patient that the test had reproduced symptoms of daily life was more often present in subjects with a $\mathrm{PC}_{20}$ of $16 \mathrm{mg} / \mathrm{mL}$ or lower suggests that treatment - in particular inhaled steroids - may be more efficacious in those subjects. For this, a prospective placeboactive trial may be relevant.

ACKNOWLEDGEMENT: The authors thank Kathe Lieber for reviewing the manuscript.

\section{REFERENCES}

1. Bateman ED, Hurd SS, Barnes PJ, et al. Global strategy for asthma management and prevention: GINA executive summary. Eur Respir J 2008;31:143-78.

2. Toelle BG, Peat JK, Salome CM, Mellis CM, Woolcock AJ. Toward a definition of asthma for epidemiology. Am Rev Respir Dis 1992;146:633-7.

3. Sterk PJ, Fabbri LM, Quanjer PH, et al. Airway responsiveness. Standardized challenge testing with pharmacological, physical and sensitizing stimuli in adults. Report working party standardization of lung function tests European Community for Steel and Coal. Official statement of the European Respiratory Society. Eur Respir J 1993;6(Suppl 1):53-83.

4. American Thoracic Society. Guidelines for methacholine and exercise challenge testing. Am J Respir Crit Care Med 1999;161:309-29

5. Troyanov S, Malo JL, Cartier A, Gautrin D. Frequency and determinants of exaggerated bronchoconstriction during shortened 
methacholine challenge tests in epidemiological and clinical set-ups. Eur Respir J 2000;16:9-14.

6. Adelroth E, Hargreave FE, Ramsdale EH. Do physicians need objective measurements to diagnose asthma? Am Rev Respir Dis 1986;134:704-7.

7. Stenton SC, Beach JR, Avery AJ, Hendrick DJ. Asthmatic symptoms, airway responsiveness and recognition of bronchoconstriction. Respir Med 1995;89:181-5.

8. American Thoracic Society. Standardization of spirometry 1987 update. Am Rev Respir Dis 1987;136:1285-307.

9. Cockcroft DW, Killian DN, Mellon JJA, Hargreave FE. Bronchial reactivity to inhaled histamine: A method and clinical survey. Clinical Allergy 1977;7:235-43.

10. Malo JL, Pineau L, Cartier A, Martin RR. Reference values of the provocative concentrations of methacholine that cause $6 \%$ and $20 \%$ changes in forced expiratory volume in one second in a normal population. Am Rev Respir Dis 1983;128:8-11.
11. Knudson RJ, Lebowitz MD, Holberg CJ, Burrows B. Changes in the normal maximal expiratory flow-volume curve with growth and aging. Am Rev Respir Dis 1983;127:725-34.

12. Pratter MR, Hingston DM, Irwin RS. Diagnosis of bronchial asthma by clinical evaluation. An unreliable method. Chest 1983;84:42-7.

13. Dales RE, Ernst P, Hanley JA, Battista RN, Becklake MR.

Prediction of airway reactivity from responses to a standardized respiratory symptom questionnaire. Am Rev Respir Dis 1987;135:817-21.

14. Yurdakul AS, Dursun B, Canbakan S, Cakaloglu A, Capan N. The assessment of validity of different asthma diagnostic tools in adults. J Asthma 2005;42:843-6.

15. Ottanelli R, Rosi E, Romagnoli I, et al. Perception of bronchoconstriction and bronchial hyper-responsiveness in asthma. Clin Sci 2000;98:681-7.

16. Devereux G, Hendrick DJ, Stenton SC. Perception of respiratory symptoms after methacholine-induced bronchoconstriction in a general population. Eur Respir J 1998;12:1089-93. 


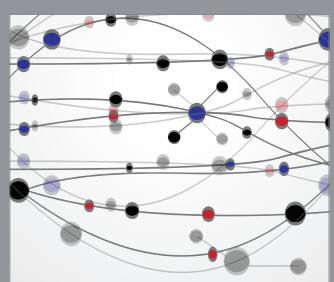

The Scientific World Journal
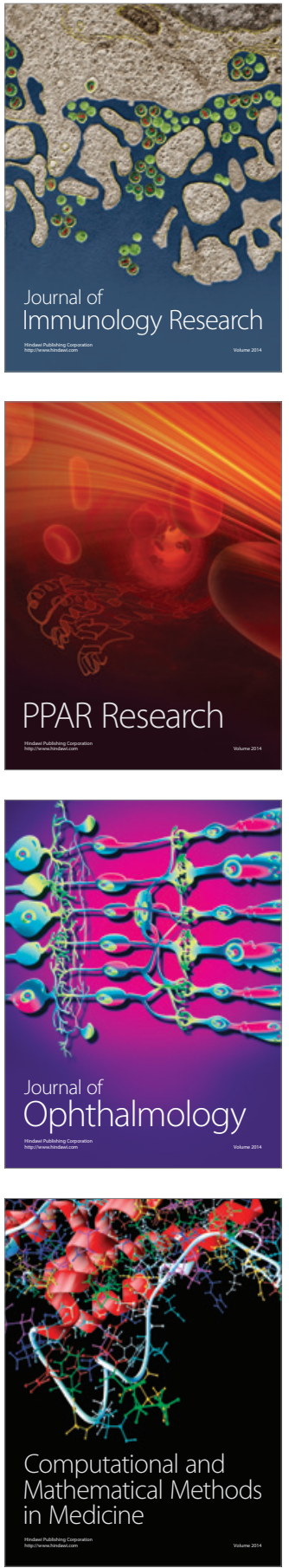

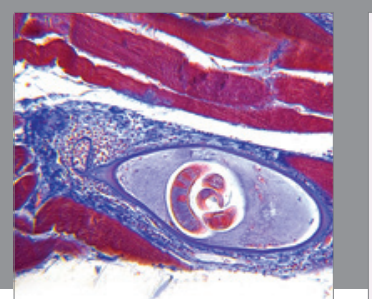

Gastroenterology Research and Practice

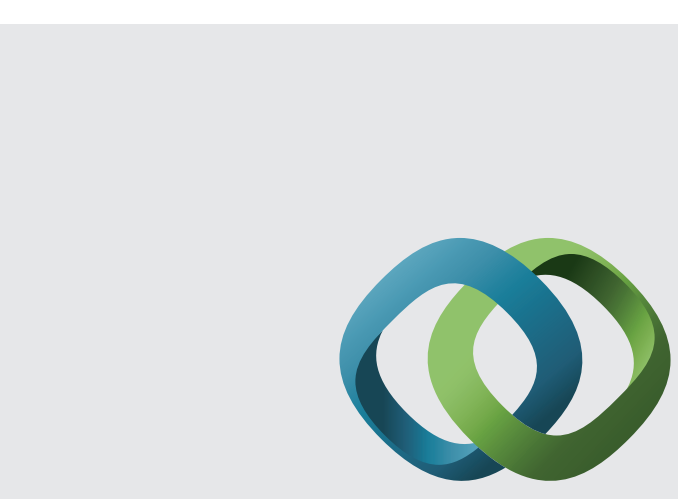

\section{Hindawi}

Submit your manuscripts at

http://www.hindawi.com
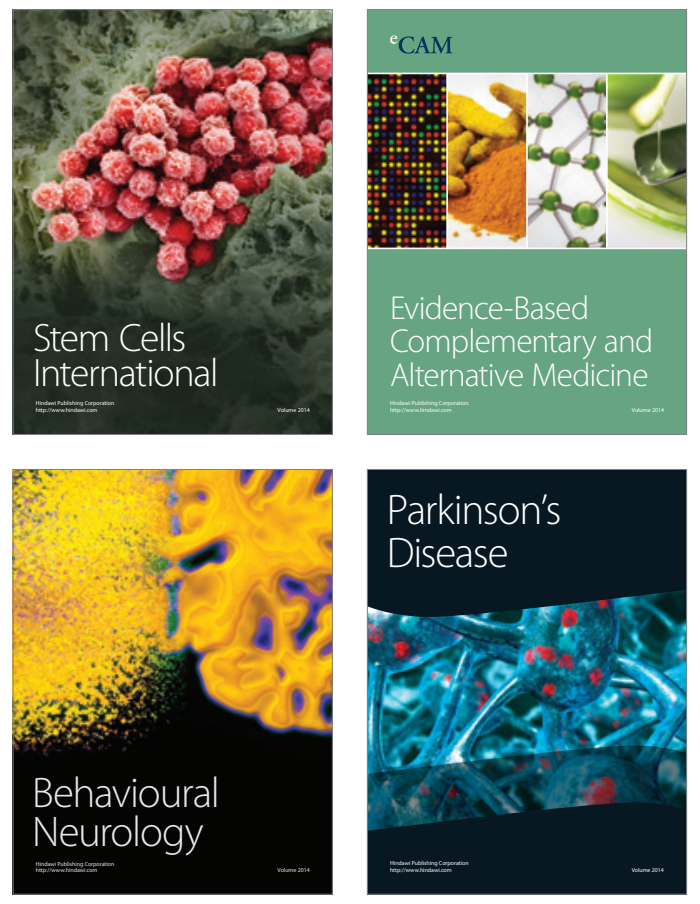
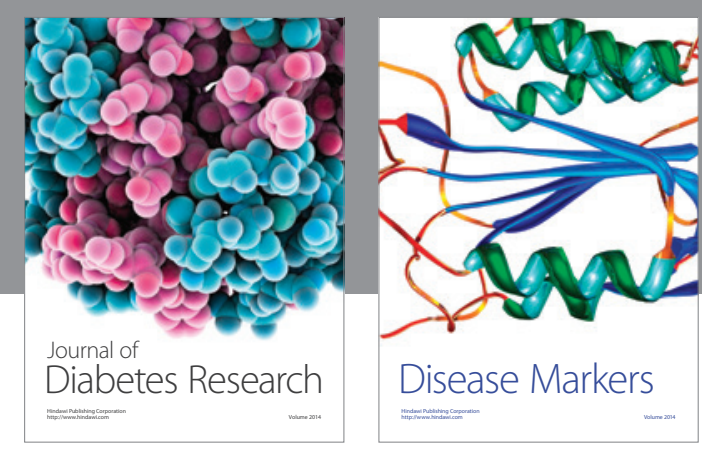

Disease Markers
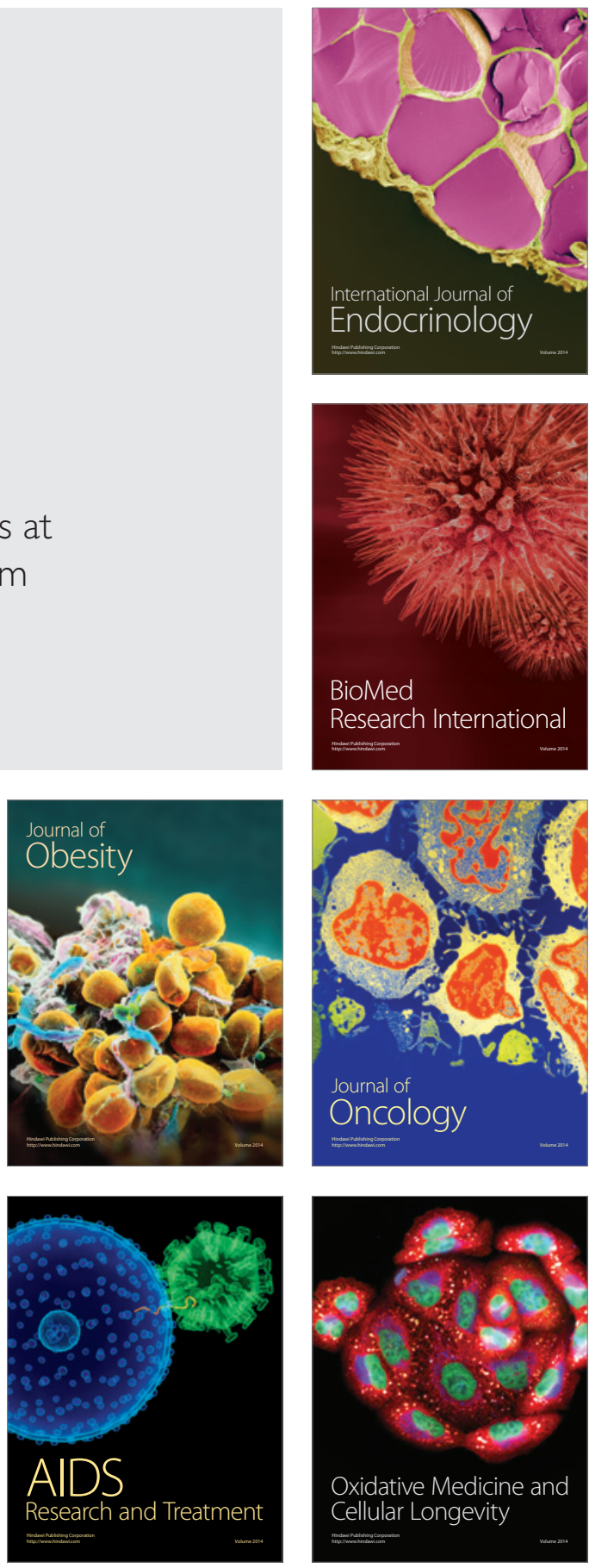